\title{
Sperm Cryopreservation of Some Freshwater Fish Species in Malaysia
}

\author{
Poh Chiang Chew and Abd. Rashid Zulkafli \\ Freshwater Fisheries Research Division, FRI Glami Lemi, Jelebu, \\ Negeri Sembilan, \\ Malaysia
}

\section{Introduction}

It has been estimated that spermatozoa can last from 200-32,000 years (Stoss \& Donaldson, 1983; Suquet et al., 2000). According to Kopeika et al. (2007), several methods of fish sperm storage has been practised including stored in medium with saturated gases, preservation at temperature above zero, in a frozen state as well as by drying. However, the low temperature approaches have been successful in fish sperm cryopreservation. Thus, cryopreservation technology offers the best means for long term storage of fish semen.

To date, successful cryopreservation of fish semen were reported in more than 200 freshwater species and 40 marine species worldwide (Gwo, 2000). Even though in general many successes have been achieved in fish semen cryopreservation, the technique remains as a method that is difficult to be standardized and use in all types of fishes. This is due to the fact that cryopreservation of sperms from different fish species required different conditions, where the protocol needs to be established individually. Even the "general protocol" of cryopreservation of fish sperm summarized by Kopeika et al. (2007) encompassed many variations when different species of fish are involved, particularly in the use of medium ingredients for the cryopreservation.

In view of need to develop individual protocol for successful cryopreservation of fish semen and considering Malaysia has a rich fish fauna with many of them unique to this tropical region, cryopreservation of fish gametes will require detailed study to create new protocol for each fish species intended for semen cryopreservation. To date in Malaysia semen cryopreservation has only been reported for several freshwater fish species, namely Probarbus jullieni, Tor tambroides, T. deuronensis, Hemibagrus nemurus, Pangasius nasutus, Hypsibarbus wetmorei, Barbonymus gonionotus and Clarias gariepinus. It has been demonstrated that semen cryoperservation plays an important role for the genetic conservation of these fish species.

Cryopreservation technology for fish semen is still not well explored in Malaysia and can be considered as new if compared to the domesticated terrestrial livestocks. Henceforth, this has opened up a new field to be explored with potential applications in aquaculture and in the conservation of the national fisheries genetic resources. Cryopreserved semen could facilitate artificial fertilization especially when mature male fishes are not available or unable to provide viable semen during certain periods of the breeding season. Semen cryopreservation may also be useful for fertilization to produce hybrids of various fish species. It also helps in reducing 
the cost and labor of maintaining broodstocks under in situ condition. In line with the mission of Department of Fisheries (DOF) Malaysia to develop and manage the national fisheries sector in a sustainable manner, the gene bank of freshwater fishes in the form of semen cryobank of Fisheries Research Institute at Glami Lemi was established in 2008. The establishment of the semen cryobank research has achieved the aim of the DOF towards establishing a national semen cryobank (gene bank) in Malaysia for conserving the genetic materials of the threatened or endangered indigenous freshwater fish species and also for those indigenous species which has potential for aquaculture.

The main focus of this chapter will be on the methodology developed for the semen cryopreservation in Malaysia of some fish species mentioned above and the various important steps and several key factors that contributed to the successes in gamete cryopreservation. In addition, the chapter will also present the current status and the challenges of fish semen cryopreservation in Malaysia, especially on the conservation of genetic resources and potential applications of gamete cryopreservation in aquaculture. Challenges in establishment and maintenance of the fish sperm cryobank are also discussed.

\section{Semen cryopresevation of freshwater fish species of Malaysia}

Malaysia has close to a hundred river systems, two natural lakes (Lake Chini and Lake Bera) and a vast freshwater water bodies and peat swamps (Baluyut, 1983). On fish biodiversity, Malaysia has approximately 616 reported freshwater fish species (Froese \& Pauly, 2003). Most of the inland fisheries resources are dominated by the cyprinids and silurids (Khoo et al., 1987). Some endemic species are found in rivers, lakes and peat swamps. In the past decades intensive development activities such as deforestation and land clearing for oil palm plantation or other agricultural uses, indiscriminate logging within and around the catchment areas and construction of dams for hydroelectricity, has led to many riverine fish species suffer high risk of extinction (Khoo et al., 1987; Jackson \& Marmulla, 2001). These development activities have resulted in habitat destruction, deterioration of water quality, water pollution and sedimentation, especially during rainy season when runoff is increased. All these certainly have direct great impacts on some fish species and the impacts are irreversible (Ho, 1995). Apart from the environmental degradation resulting from development, other causes of loss in inland fisheries biodiversity are attributed to overexploitation due to strong market demand, the use of illegal and destructive fishing gears such as poisoning and electro-shocker and the introduction of invasive exotic species (Dudgeon, 2002; Allan et al., 2005). The indigenous species such as Isok barb (Probarbus jullieni), Malaysian Mahseer (Tor spp.), Mad barb (Leptobarbus hoeveni), Hampala barb (Hampala macrolepidota), knife fish (Chitala lopis), climbing perch (Anabas testudineus), snakeheads (Channa spp.), Asian arowana (Scleropages formosus), the pangasiid catfishes (Pangasius nasutus, Pangasigodon waandersii), giant river catfish (Wallago leerii), large headed walking catfish (Clarias macrocephalus) and giant gouramy (Osphronemus goramy) have dwindled in great numbers continuously due to unsustainable fishing activities. At present, most Malaysian fish species could only be conserved probably in the inaccessible or remote areas of the country.

It is no doubt that continuing habitat destruction, overfishing and competition for food from the invading fish species are leading to loss of inland fisheries biodiversity even before much of them could be documented. The lack of data on the indigenous species will 
subsequently impede efforts to better utilize and manage the nation's inland fisheries resources in a sustainable manner, and can eventually resulting in threatened, endangered or extinction of fish species in Malaysia. With respect to National Biodiversity Policy, it is therefore vital to protect and safeguard the indigenous fisheries resources while the species still exist in the wild. Realizing the risk of depleting fish stocks from natural waters, studies in domestication, management and husbandry of broodstocks, artificial breeding, grow out, nutrition and effort in stock enhancement via restocking of selected indigenous freshwater fish species have been carried out by the Department of Fisheries, Malaysia ever since 1980's. The species which have been studied and documented were the indigenous catfishes (Clarias macrocephalus and C. batrachus), Tropical bagrid catfish (Hemibagrus nemurus), Hampala barb (Hampala macrolepidota), Isok barb (Probarbus jullieni), Malaysian Mahseer (Tor tambroides), local pangasiid catfish (Pangasius nasutus) (Pathmasothy \& Omar, 1982; Pathmasothy, 1985; Saidin, 1986; Thalathiah et al., 1988; Mohamad-Zaini, 1992; Thalathiah et al., 1992; Ahmad-Ashhar, 1992; Ahmad-Ashhar \& Haron, 1994; Ahmad-Ashhar, 1996; Suhairi, 1996; Suhairi et al., 1996; Ahmad-Ashhar, 1998).

In 2007, cryopreservation of semen was implemented as one of the ex situ conservation approach, with the exotic species such as the Javanese barb (Barbonymus gonionotus) and African catfish (Clarias gariepinus) used as the model species to examine the various suitable formulations diluents and skill development in semen cryopreservation. These two species were chosen because they are domesticated species, which are available abundantly in Malaysia and able to breed easily in captivity. In Malaysia, very little work was done on semen cryopreservation in fish species and study on fish semen cryopreservation is still at its infancy. So far only a few indigenous fish species, namely the P. jullieni, Tor spp, $H$. nemurus, $P$. nasutus and $H$. wetmorei were studied. Of which only studies on the P. jullieni, Tor spp., and H. nemurus were reported (Chew et al., 2010a; Chew et al., 2010b; Muchlisin et al., 2004), while studies on other species remain unpublished. The biology, ecology and reproduction biology of these indigenous fish species are described in the following:

\subsection{Probarbus jullieni}

P. jullieni (English name: Isok barb or Jullien's Golden Carp or seven-striped barb) of family Cyprinidae (Figure 1a) is commonly known as Temoleh or Temelian among Malaysians. This species is listed in the Convention on International Trade in Endangered Species of Wild Fauna and Flora (CITES), Appendix 1 and the IUCN Red List as the endangered species (Hogan et al., 2009; IUCN, 2009). Therefore, conservation of this species is in urgent needed. Isok barb is a migratory species inhabiting river channels with water depth more than $10 \mathrm{~m}$ and is endemic to the Pahang River and Perak River in Peninsular Malaysia and the Mekong River basins of Indochina (Roberts, 1992). However, the drastic depletion of the numbers of Isok barb in Perak River was reported ever since the construction of Chenderoh Dam in 1930s. The dam created a physical barrier at the Perak River that permanently blocked the migration path of the Isok barb and increased water level further destroyed the spawning ground of this species (Khoo et al., 1987). Although the Isok barb can grow to reach the weight exceeded $70 \mathrm{~kg}$, like the size of a human being (Baird, 2006), the landing of large size Isok barb $(>10 \mathrm{~kg})$ has rarely occurred in the past 10 years.

Isok barb is a seasonal-bred species. In Malaysia, induced breeding of this species was carried out successfully in FRI Glami Lemi (formerly known as Freshwater Fisheries Research Centre) 
in 1990s (Ahmad-Ashhar, 1992; Ahmad-Ashhar \& Haron, 1994). In its natural environment, this species spawn in fast flowing deep waters with sandy bottom. Chew et al. (2010a) reported that the spawning behavior of $P$. jullieni in captivity very much associated with the monsoons. Nevertheless, the breeding season of the cultured Isok barb was reported to be 1-2 months earlier (October to January) than the wild populations (December to February).

\subsection{Tor spp. (T. tambroides and T. deuronensis)}

The Malaysian Mahseer, Tor spp. (family: Cyprinidae) or locally known as Kelah, Empurau, Semah or Pelian, is highly sought for its value as a food fish, game fish and ornamental fish (Inger \& Chin, 1962; Mohsin \& Ambak, 1991; Kottelat et al., 1993). Two valid Tor species were identified and described in Malaysia, i.e. T. tambroides and T. douronensis (Roberts, 1989; Kottelat et al., 1993; Rainboth, 1996; Zhou \& Chu, 1996) (Figure 1b and 1c). Of the two Tor spp., the T. tambroides is more favourable as food fish and can fetch up to about USD 100 - USD 220 per $\mathrm{kg}$ and thus is the most expensive freshwater food fish in Malaysia. Malaysian Mahseer occurs in most undisturbed and clear flowing upstream rivers, reservoir systems and lotic habitats throughout the East and Southeast Asia. The major geographical locations of Malaysian Mahseer are Pahang, Perak, Terengganu, Kelantan, Sabah and Sarawak (Ng, 2004; Ambak et al., 2007). Similar to other indigenous fishes in Malaysia, the wild populations of Malaysian Mahseer are declining over the years as the consequences of over-exploitation, natural habitat degradation and water pollution. Therefore, Malaysian Mahseer is now classified nationally as ecologically threatened (Ingram et al., 2005).

The taxonomic status of species within the genus Tor has been highly contentious due to plasticity of many external morphological features resulted from considerable geographical and ecological variability (Tsigenopoulos \& Berrebi, 2000; Nguyen et al., 2007). Therefore, species identification based on morphological comparison sometimes could be confusing to most people who are not trained in fish taxonomy. Ability to differentiate between the Malaysian Mahseer and the Copper Mahseer (Neolissochilus spp.) is another difficult task hampered most of the fish farmers or aqua-culturists. The Copper Mahseer is not a desirable species and thus its value in term of market price is very much lower compared to the Malaysian Mahseer. At present, the seed supply of Malaysian Mahseer is still depending solely on the captive wild stock. As such, those who want to culture this species will have to bear with the risk of getting seed stock that comprises the mixture of these two species. Therefore, a more effective method for species identification by using DNA markers such as the mitochondria DNA (mtDNA) sequences and microsatellte markers are seen as potential in solving this problem (Nguyen et al., 2006a; Nguyen et al., 2006b; Nguyen et al., 2008; Nguyen, 2008).

The first successful hormonal induction spawning of T. tambroides under captive pondreared environment was reported by Ingram et al. (2005). In captive condition, T. tambroides seems to spawn all year round. Brood fish of both sexes may strip up to a few times in a year. However, it is reported that geographical reproductive diversity, diet and environment conditions such as changes in temperature, water level, $\mathrm{pH}$, flow velocity, turbidity, rain falls, collectively trigger the Mahseer to spawn (Dobriyal et al., 2000). Malaysian Mahseer is also a large riverine species and that can grow up to $30-50 \mathrm{~kg}$. In the culture condition, the growth rate of Malaysian Mahseer is relatively slow compared to 
other aquaculture species. This species usually took up to three years to reach the marketable size of $1.5-2.0 \mathrm{~kg}$.

\subsection{Hemibagrus nemurus}

The tropical bagrid catfish, H. nemurus (previously known as Mystus nemurus) of family Bagridae and with the vernacular name Baung (Figure 1d), is a widely distributed food fish found in most of the inland water bodies in Malaysia (Khan et al., 1995). The occurrence of this species in brackish water was also reported (Inger, 1955). The tropical bagrid catfish is a bottom feeder and fed on a wide range of food from small teleosts, crustaceans, benthic invertebrates to the detritus (Khan, 1987). This species is potential for aquaculture as it receives good acceptance from the local market due to its tender and non-bony meat. This carnivorous species is also a popular species in sport fishing. The artificial spawning of tropical bagrid catfish via hormonal induction using the heteroplastic pituitary extract in combination with human chorionic gonadotropin (HCG) was reported by Thalathiah et al. (1988, 1992). According to Khan et al. (1995), a bimodal male and female gonad somatic index (GSI) pattern throughout a year was shown in this species, suggesting this species could spawn twice in a year.

\subsection{Pangasius nasutus}

The local pangasiid catfish, $P$. nasutus of family Pangasiidae and with local name Patin Buah, (Figure 1e) is a native river catfish endemic to Pahang River in Malaysia. As commented by Hung et al. (2004), catfishes from the family Pangasiidae are of great economical importance in Southeast Asia. P. nasutus is one of the favorite food fish due to its white and tender flesh. This omnivorous species commands a high market value (USD 20 per $\mathrm{kg}$ ) in local market. In the wild, P. nasutus fed mainly on the bivalves, mollusks, gastropods and other benthic organisms especialy on sandy bottom rivers (Roberts \& Vidthayanon, 1991). Because of its economic value and declining population in the natural waters, this has created popularity and awareness to conserve and culture this species. The first successful induced spawning of $P$. nasutus was reported in 2005. This species is also a batch spawner and exhibits a single-modal GSI pattern throughout the whole year. During the spawning season, multiple releases of eggs from a single female broodfish were observed during the single period (Mohd-Zafri, 2006). The breeding season of this species is associated with rainfalls or monsoons between May - July (Maack \& George, 1999).

\subsection{Hypsibarbus wetmorei}

Morphologically Hypsibarbus wetmorei is quite similar to the Javanese Barb, Barbonymus gonionotus except the appearance of turmeric-like yellow colour on its body (Figure 1f) where the vernacular name Kerai Kunyit is given. This species is of the family Cyprinidae. Kerai Kunyit is highly regarded as a food fish and thus it is a potential aquaculture species. In Malaysia, this species is found to be endemic in Pahang River. Until today, the biology, ecology and repoductive behaviour of this species is not well studied and limited documentation on the species is available. By far, only study on species identification of Hypsibarbus spp. (included $H$. wetmorei) using PCR-RFLP method was reported by Jantrarotai et al. (2007). 


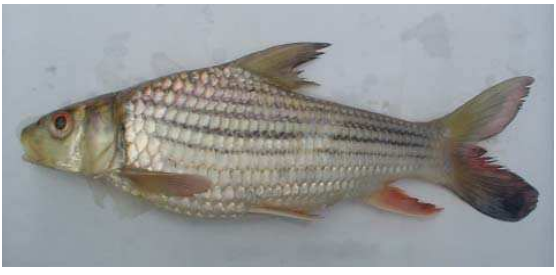

a

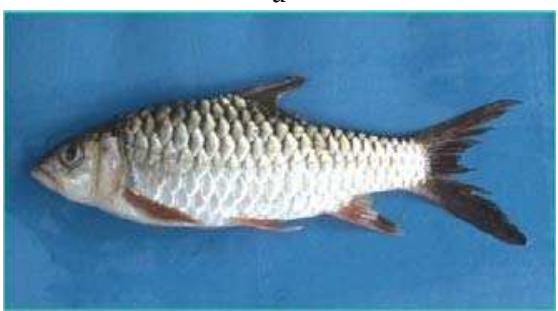

C

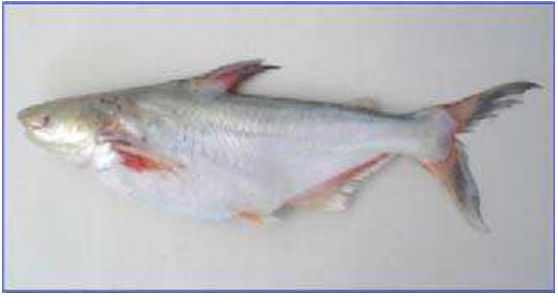

$\mathrm{e}$

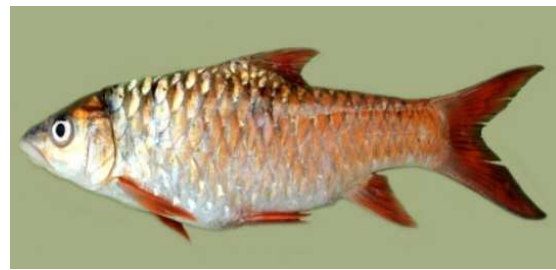

b

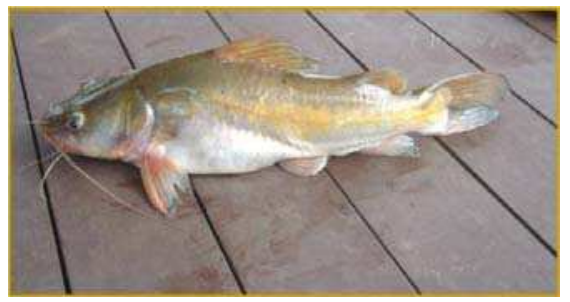

d

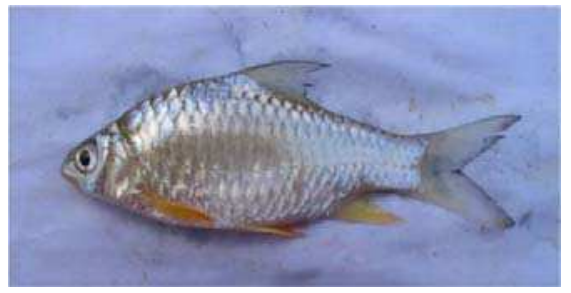

$\mathrm{f}$

Fig. 1. Photos of the Malaysian fishes involved in the cryopreservation studies, (a) Isok barb (P. jullieni), (b) Malaysian Mahseer (T. tambroides), (c) Malaysian Mahseer (T. deauronensis), (d) Tropical bagrid catfish (H. nemurus), (e) Local pangasiid catfish (P. nasutus), and (f) Kerai Kunyit (H. wetmorei).

\section{Methodology employed for semen cryopreservation of freshwater fishes in Malaysia}

As in cryopreservation of other fish species, the cryopreservation of the semen of freshwater fishes from Malaysia to be discussed later falls under the following general procedures (i) collection of semen, (ii) dilution of semen sample, (iii) semen sample packaging, (iv) equilibration, (v) freezing, (vi) cryo-storage, and (vii) thawing. Successful cryopreservation of fish sperm very much depends on a range of factors in each step of the cryopreservation procedures as highlighted by Kopeika et al. (2007).

\subsection{Collection of fish semen}

Mature and healthy males broodfish were selected and anaesthesized using MS222 or clove oil according to the dosage recommended by the manufacturer. Semen sample was expelled from the male fish by gentle abdominal pressure and collected into a clean and dry tube. Extra precaution should be taken while collecting semen sample. Contamination of sample with blood, water, urine or the feces should be avoided as these contaminants significantly 
reduced the semen quality and caused poor post-thaw sperm motility. The semen samples were then transferred back to laboratory for quantification of the fresh sperm quality and proceed with further dilution before freezing procedure. The sperm motility rates and sperm concentration of the freshly collected semen sample was evaluated prior to cryopreservation. In order to obtain good post-thaw motility, only semen samples showing sperm motility $\geq 70 \%$ were used for cryopreservation.

\subsection{Dilution of semen sample}

The semen samples with good quality were subsequently diluted at an appropriate sperm to diluent ratio, with suitable extender solution and cryo-protectant. Sperm to diluent ratios ranged between 1:3 to 1:9 were reported to produce best results in fish sperm cryopreservation studies (Scott \& Baynes, 1980; Lahnsteiner et al., 1996). Gwo (2000) reported the fish sperm could loss its viability in high dilution ratio especially in marine species. The type of extender solution, cryoprotectant and dilution ratio that were optimum for each Malaysian fish species studied were summarized in Table 1. The type of diluents and dilution ratios workable to preserve sperm motility appear to vary among different fish species. Thus each of these parameters needs to be optimized accordingly via a series of experimentations.

The extender solution helps to maintain sperm viability prior to and during the freezing process. Extender solution is a balanced salt buffer of specific $\mathrm{pH}$ and osmotic strength. Apart from salts, sometimes extender solution is prepared with addition of organic compounds such as glucose. The nature of the effect of extenders is based on the control of $\mathrm{pH}$ and salt concentration as well as the supply of energy, and can extend the functional life and fertilizing capability of the sperm (Tiersch, 2000). Cryoprotectants function to protect cells from cryodamage or cryo-injury during freezing and thawing process. The permeating cryoprotectants, namely dimethyl sulfoxide, methanol, ethylene glycol and propylene glycol are among the most frequently used cryoprotective agents among the aquatic organisms (Lahnsteiner et al., 1997; Tiersch, 2000; Tiersch, 2006). However, the permeating cryoprotectants are often toxic to cells, and thus the choice of the types of cryoprotectant and their optimal concentration should be at a balance between protection and toxicity. On the other hand, the non-permeating cryoprotectants such as sucrose, glucose and polymers (e.g. alginate) were often used in combination with the extender solution in the diluents. Sometimes, a combination of different cryoprotectants in certain ratios could help improving the post-thaw motility. The studies of African catfish in our laboratory has shown that a combination of methanol and $\mathrm{N}, \mathrm{N}$ dimethylacetamide at ratio $70 \%: 30 \%$ produced significant higher post-thaw motility compared to the use of a single cryoprotectant in sample dilution. Tiersch (2000) has also reported that the application of cryoprotectant at concentration between $5 \%$ to $20 \%$ ususally provides good protection in most fish species. The protective effect and optimal concentration of cryoprotectants could be species specific (Gwo et al., 1991; Suquet et al., 2000; Rideout et al., 2003). Therefore, the optimal concentration needs to be determined individually in each species studied through experimentations.

For Isok barb (P. jullieni), Malaysian Mahseer (Tor spp.), local pangasiid catfish (P. nasutus) and Kerai Kunyit ( $H$. wetmorei), a total of 14 extender formulations, five types of cryoprotectants (dimethyl sulfoxide, ethylene glycol, glycerol, methanol and N,N dimethylacetamide) with concentrations between 5-20\% (v/v), semen to diluent ratios (1:1 to 1: 14) were examined as described by Chew et al. (2010a). This may be compared with Muchlisin et al. (2004) who used three extender solutions (the Ringer, physiological saline 
and saline solution); four types of cryoprotectants (DMSO, ethanol, glycerol and methanol) at three concentrations $(5 \%, 10 \%$ and $15 \%)$ and three sperm to diluent ratios $(1: 20,1: 30$ and 1:40) in tropical bagrid catfish sperm cryopresevation.

\begin{tabular}{|c|c|c|c|c|}
\hline Species & $\begin{array}{l}\text { Chemical composition of extender } \\
\text { solution }\end{array}$ & $\begin{array}{l}\text { Type of } \\
\text { cryoprotectant \& } \\
\text { concentration } \\
(\mathrm{v} / \mathrm{v})\end{array}$ & $\begin{array}{l}\text { Sperm } \\
\text { to } \\
\text { diluent } \\
\text { ratio } \\
\end{array}$ & Reference \\
\hline $\begin{array}{c}\text { B. } \\
\text { gonionotus }\end{array}$ & $\begin{array}{c}\text { Modified from Kurokura et al. } 1984 \text { - } \\
62 \mathrm{mM} \mathrm{NaCl} 134 \mathrm{mM} \mathrm{KCl}_{1} 1.5 \mathrm{mM} \\
\mathrm{CaCl}_{2}, 0.4 \mathrm{mM} \mathrm{MgCl}_{2}, 2.4 \mathrm{mM} \\
\mathrm{NaHCO}_{3} \\
\text { (Horvath et al., 2003) }\end{array}$ & Methanol 10\% & $1: 4-1: 6$ & $\begin{array}{l}\text { Unpublished } \\
\text { data }\end{array}$ \\
\hline $\begin{array}{l}\text { C. } \\
\text { gariepinus }\end{array}$ & $\begin{array}{c}\text { Ringer solution - } 128 \mathrm{mM} \mathrm{NaCl}^{2.7} \\
\mathrm{mM} \mathrm{KCl}, 1.4 \mathrm{mM} \mathrm{CaCl}_{2}, 2.4 \mathrm{mM} \\
\mathrm{NaHCO}_{3} \\
\text { (Kurokura et al., 1984) }\end{array}$ & $\begin{array}{l}\text { Methanol + DMA } \\
\quad(70: 30) 8 \%\end{array}$ & $1: 6$ & $\begin{array}{l}\text { Unpublished } \\
\text { data }\end{array}$ \\
\hline P. jullieni & 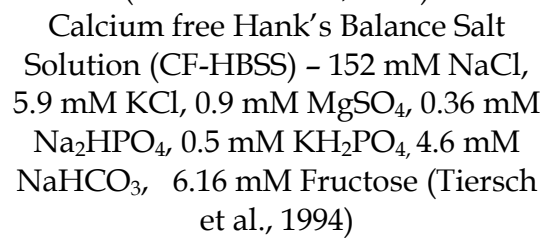 & Methanol 9 - 10\% & $1: 3-1: 5$ & $\begin{array}{l}\text { Chew et al., } \\
2010 \mathrm{a}\end{array}$ \\
\hline Tor spp. & $\begin{array}{l}202 \mathrm{mM} \mathrm{D}(+) \text {-glucose monohydrate, } \\
51.5 \mathrm{mM} \text { sodium chloride and } 6 \mathrm{mM} \\
\text { sodium bicarbonate, with pH } 7.1 \text { to } 7.8 \\
\text { and osmolality } 309 \pm 30 \mathrm{mOsmol} / \mathrm{kg}\end{array}$ & DMSO $10 \%$ & $1: 7$ & $\begin{array}{l}\text { Chew et al., } \\
2010 \text { b }\end{array}$ \\
\hline P. nasutus & CF-HBSS (Tiersch et al., 1994) & Methanol 9 - $10 \%$ & $1: 7$ & $\begin{array}{c}\text { Unpublished } \\
\text { data }\end{array}$ \\
\hline $\begin{array}{l}H . \\
\text { wetmorei }\end{array}$ & $\begin{array}{c}\text { Modified Fish Ringer - } 111 \mathrm{mM} \mathrm{NaCl} \text {, } \\
40.2 \mathrm{mM} \mathrm{KCl}, 2.1 \mathrm{mM} \mathrm{CaCl}_{2}, 2.4 \mathrm{mM} \\
\mathrm{NaHCO}_{3} \text { (Wolf, 1963) }\end{array}$ & Methanol 9 - $10 \%$ & $1: 4-1: 7$ & $\begin{array}{l}\text { Unpublished } \\
\text { data }\end{array}$ \\
\hline $\begin{array}{c}H . \\
\text { nemurus }\end{array}$ & $\begin{array}{c}\text { Modified Fish Ringer - } 128 \mathrm{mM} \mathrm{NaCl} \text {, } \\
2.7 \mathrm{mM} \mathrm{KCl}_{1} 1.4 \mathrm{mM} \mathrm{CaCl}_{2}, 2.4 \mathrm{mM} \\
\mathrm{NaHCO}_{3}, 25.3 \mathrm{mM}_{\text {glucose }}\end{array}$ & Methanol 10\% & $1: 20$ & $\begin{array}{l}\text { Muchlisin et } \\
\text { al., } 2004\end{array}$ \\
\hline
\end{tabular}

Table 1. A list of extender solution and its composition, type of cryoprotectant and its optimal concentration and sperm to diluent ratio for successful semen cryopreservation of various species of freshwater fishes in Malaysia.

\subsection{Packaging and equilibration of diluted semen sample}

In this procedure which is performed after the addition of extender solution and cryoprotectant, the diluted semen sample is packed into polyethylene (PE) straws (Chew et al., 2010a; Chew et al., 2010b) or cryo-vials (Muchlisin et al. ,2004). Extended semen sample is subjected to equilibration at temperature $<10^{\circ} \mathrm{C}$ prior to freezing procedure. The duration taken for equilibration is the time required for the cryoprotectant to permeate the cells. Equilibration duration between $15 \mathrm{~min}$ to $3 \mathrm{~h}$ has been practised for Malaysian fish species 
sperm cryopreservation and was found to be successful in maintaining a good post-thaw sperm motility (Chew et al., 2010b). In most circumstances, the equilibration duration is set at 15 to $30 \mathrm{~min}$, but it can be varied depending on the type and concentration of cryoprotectant used (Tiersch, 2000).

\subsection{Sperm cryopreservation}

Cryopreservation involves the removal of excess water from the inside of the cell to the exterior where it can form ice (Tiersch, 2000). A two-step rapid freezing method was used for semen cryopreservation in Isok barb, Malaysian Mahseer, local pangasiid catfish and Kerai Kunyit. After the equilibration procedure, semen samples of these species were subjected to liquid nitrogen vapour exposure for 5-10 $\mathrm{min}$ in an insulated styrofoam cooler box filled with liquid nitrogen, with the samples placed between 3 to $4 \mathrm{~cm}$ above the liquid nitrogen, after which the samples were directly plunged into liquid nitrogen. For tropical bagrid catfish (Muchlisin et al., 2004), the semen samples were equilibrated on crushed ice $\left(0^{\circ} \mathrm{C}\right)$ for $5 \mathrm{~min}$. After the equilibration procedure, the samples were then placed in an ice box containing dry ice $\left(-120^{\circ} \mathrm{C}\right)$ for $5 \mathrm{~min}$ and subsequently plunged into liquid nitrogen.

Besides the styrofoam cooler and ice box, the vapour shipper is another choice of method could be used for the freezing of fish semen samples. To cryopreserve semen samples by using dry shipper, the extended and packed semen sample was transferred into the fully charged vapour shipper and subsequently transferred and stored in liquid nitogen. The use of the vapour shipper method in freezing as reported in Tor spp. (Chew et al., 2010b) was convenient to be used in the field. Such method is simple to use, the cooling rate is more consistent and controllable and it consumes less liquid nitrogen and requires less space compared to the styrofoam cooler box or ice box method.

In our opinion, the use of the sophisticated bench top type of controlled rate programmable freezer is not practical in cryopreservation of fish semen in some laboratories because of difficulty to move this equipment from one location to another. Unfortunately portable type of controlled rate programmable freezer is not user friendly, time consuming and limited number of samples could be processed at a single run. Compared with programmable freezer, the two-step freezing method employing insulated styrofoam cooler box or ice box is simpler, rapid and more cost effective. Nevertheless, the main shortcomings of this simple freezing method is the inconsistency in cooling rates and non-reproducible cryopreservation experiments if performed by different operators.

\subsection{Thawing}

Thawing is a process to recover the sperm cells from the dormant stage in ultra low temperature. Frozen semen is usually thawed at $40^{\circ} \mathrm{C}$, with different optimal durations applied according to the type of packaging and the storage volume as shown in Table 2.

\begin{tabular}{ccc}
\hline Type of packaging & Volume of semen & Duration of thawing \\
\hline & $0.25 \mathrm{~mL}$ & $4 \mathrm{~s}-6 \mathrm{~s}$ \\
PE straw & $0.5 \mathrm{~mL}$ & $6 \mathrm{~s}-8 \mathrm{~s}$ \\
& $1.2 \mathrm{~mL}$ & $12 \mathrm{~s}-15 \mathrm{~s}$ \\
\hline Cryo-vial & $5 \mathrm{~mL}$ & $5 \mathrm{~min}$ \\
\hline
\end{tabular}

Table 2. The optimal durations used to thaw the frozen semen samples of freshwater fish species in Malaysia in different types of packaging and storage volume. 


\subsection{Egg fertilization}

A cryopreservation protocol developed for a species is considered success if the semen that cryopreserved according to the certain protocol could successfully fertilize eggs and produced offspring. Fresh semen is usually included in the control treatment. The optimal sperm to egg ratio used should be determined prior to fertilization. The sperm: egg ratio at approximately 250,000:1 is usually sufficient and worked well in most species in our laboratory. However, other sperm to egg ratios from 1000:1 to 500000: 1 were tested by Butts et al. (2009) and 100 000: 1 was found to yield the best fertilization performance in Atlantic cod. The dry fertilization method is favorable in the fertilization test for freshwater fish and thus was applied for all Malaysian fish species studied in our laboratory. In the dry fertilization method, both eggs and sperms were mixed well before hatchery water was later added into the sperm/egg mixture to water-harden the fertilized eggs. After rinsing with hatchery water, fertilized eggs were then incubated in aquarium (with or without using a hatching trough depended on species). Water temperature was kept at room temperature between $23-28^{\circ} \mathrm{C}$ throughout the period of incubation. The duration of embryo development varied between species. Therefore, the duration required for the fertilized egg to hatch is also varied among different species.

\section{Discussion on semen cryopreservation of Malaysian freshwater fish species}

The successful semen cryopresevation of several Malaysian fish species e.g. P. jullieni, T. tambroides, T. deuronensis, $H$. bleekeri, $P$. nasutus and $H$. wetmorei using various methods of cryopresevation discussed above may be evaluated via analyses on the sperm motility, fertilization, hatching ability, etc.

\subsection{Quality of semen}

Sperm motility for the freshly collected semen from the healthy broodfish is usually ranged between $90-100 \%$ motility provided that the sperm sample was not activated prior to the actual cryopreservation processes or contaminated by water or urine while sampling was carried out. However from our observation, sperm motility of most freshwater fishes dropped to $<10 \%$ after $24 \mathrm{~h}$ if the sample was not extended using suitable extender solution, even though the sample was kept cool in a refrigerator $\left(0-5^{\circ} \mathrm{C}\right)$.

Sperm concentration is one of the important characteristic that determines the sperm quality of an individual male (Billard, 1986; Suquet et al., 1992; Billard et al., 1995). The sperm concentrations of all Malaysian fish species studied were between $2.2 \times 10^{8}$ to $6.2 \times 10^{10}$ sperm cells per $\mathrm{mL}$ and this is in agreement with the studies by Leung \& Jamieson (1991). On the other hand, short lifespan after activation is the typical characteristic of spermatozoa of freshwater fish species. The duration of sperm motility of most freshwater fishes is normally $<1 \mathrm{~min}$ after the sperms are activated (Billard \& Cosson, 1992; Lahnsteiner \& Patzner, 2008). Duration of sperm motility of Tor spp. was about 40-50 s and it slowed down drastically after $20 \mathrm{~s}$ of progressive movements (Chew et al., 2010b). For Isok barb, it was about $20 \mathrm{~s}$ and slowed down after $10 \mathrm{~s}$ of progressive movements. Table 3 shows the range of sperm concentrations and motility duration in each Malaysian species studied at FRI Glami Lemi. 


\begin{tabular}{|c|c|c|}
\hline Species & $\begin{array}{l}\text { Sperm count (Number of cells } \\
\text { per } \mathrm{mL} \text { ) }\end{array}$ & Duration of motility $\left(^{*}\right)$ \\
\hline $\begin{array}{l}\text { Javanese barb } \\
\text { (B. gonionotus) }\end{array}$ & $2.52 \times 10^{9}-1.03 \times 10^{10}$ & $<15 \sec (10 \mathrm{~s})$ \\
\hline $\begin{array}{l}\text { African catfish } \\
\text { (C. gariepinus) }\end{array}$ & $5.44 \times 10^{9}-1.14 \times 10^{10}$ & $15-30 s,(13 s)$ \\
\hline $\begin{array}{l}\text { Isok barb } \\
\text { (P. jullieni })\end{array}$ & $4.00 \times 10^{8}-6.24 \times 10^{10}$ & $20 \mathrm{~s},(10 \mathrm{~s})$ \\
\hline $\begin{array}{l}\text { Malaysian Mahseer } \\
\text { (Tor spp.) }\end{array}$ & $2.20 \times 10^{8}-5.98 \times 10^{9}$ & $40-50 \mathrm{~s},(20 \mathrm{~s})$ \\
\hline $\begin{array}{l}\text { Local pangasiid catfish } \\
\quad(P . \text { nasutus })\end{array}$ & $6.60 \times 10^{8}-1.36 \times 10^{10}$ & $25-50 s,(15 s)$ \\
\hline $\begin{array}{l}\text { Kerai Kunyit } \\
\text { (H. wetmorei) }\end{array}$ & $7.30 \times 10^{9}-1.33 \times 10^{10}$ & $20-70 \mathrm{~s},(20 \mathrm{~s})$ \\
\hline
\end{tabular}

*Duration of progressive movement before slowed down and finally stopped

Table 3. Sperm concentration and motility duration of each freshwater fish species studied at FRI Glami Lemi.

Osmolality is another critical variable in sperm quality (Honeyfield \& Krise, 2000). As seen in many studies, seminal plasma osmolality among males fish is highly variable (Aas et al., 1991). According to Babiak et al. (2001), the extender solution that worked well to cryopreserve spermatozoa of a species should posses the ability to maintain the sperm cell viability by inhibiting sperm motility. The key of success is via the use of an extender solution which is almost isotonic or mimicking the seminal plasma of that particular species. Therefore, it is crucial to know the seminal fluid osmolality of a species before media and diluents for that particular species can be formulated.

In all species of Malaysian fishes studied, sperm motility generally reduced after freezing and thawing process compared to the sperm motility before any freezing procedure. In P. jullieni, the motility of cryopreserved semen has reduced by approximately $45 \%$ compared to the fresh semen. A reduction of sperm motility by an average of $15 \%$ and $30 \%$ in T. tambroides and $T$. deuronensis respectively was observed. In general, sperm motility reduced between $10-70 \%$ on average in the species studied (Table 4). These observations are similar to studies in several other species such as Cyprinus carpio L. (Wamecke \& Pluta, 2003), Oncorhynchus mykiss (Lahnsteiner et al., 1996) and Scophthalmus maximus (Dreanno et al., 1997).

\begin{tabular}{cll}
\hline Species & Motility \% \\
\cline { 2 - 3 } & Before freezing & Post-thaw \\
\hline Javanese barb & $88-97 \%$ & $15-65 \%$ \\
African catfish & $60-100 \%$ & $15-70 \%$ \\
Isok barb & $85-100 \%$ & $30-84 \%$ (Mean: $49 \%$ ) \\
Malaysian Mahseer & $85-100 \%$ & $35-89 \%$ (Mean: 55\%) \\
Local pangasiid catfish (Patin Buah) & $85-100 \%$ & $35-70 \%$ \\
Kerai Kunyit & $90-100 \%$ & $35-80 \%$ \\
Tropical bagrid catfish (Muchlicin et al. 2004) & $80-94 \%$ & $58 \%$ \\
\hline
\end{tabular}

Table 4. Sperm motility (\%) of the freshwater fish species studied before freezing and after thawing procedures 
For all Malaysian fish species studied, the post-thaw motility rates of the cryopreserved sperm demonstrated similar values $(\mathrm{p}>0.05)$ even after a year of cryostorage as long as the semen samples are submerged well in the liquid nitrogen and without disturbance during the storage period.

\subsection{Fertilization ability and hatching rate}

In both Malaysian Mahseer and Isok barb, egg fertilization ability and hatching rates were found significantly lower $(\mathrm{p}<0.05)$ by using cryopreserved sperm compared with those fertilized using fresh sperm. The speed of embryos development was similar among the fertilized eggs using both cryopreserved and fresh sperm. Besides that, no significant difference $(p>0.05)$ was found in the egg fertilization percentages between newly cryopreserved semen and semen samples after a year of cryo-storage in both species. The performance of egg fertilization and hatching by using cryopreserved semen in four species of freshwater fish species studied in our laboratory is shown in Table 5.

\begin{tabular}{ccc}
\hline Species & Fertilization $(\%)$ & Hatching $(\%)$ \\
\hline Javanese barb & $12-100$ & $5-75$ \\
African catfish & $21-37$ & $19-32$ \\
Isok barb & $1.2-10$ & $0.8-4.6$ \\
Malaysian Mahseer & $20-55$ & $20-53$ \\
\hline
\end{tabular}

Table 5. Fertilization and hatching performance using cryopreserved sperm in several freshwater fish species carried out at FRI Glami Lemi

Quantitatively the numbers of hatchings from the cryopreserved semen were low, but qualitatively the hatchlings are visually normal and physically active and healthy as those from the fresh semen. Fingerlings produced from the cryopreserved semen from all four species showed normal development compared with those produced from the fresh semen.

\section{Dependence of egg fertilization on semen cryopreservation methods}

For the sperm cryopreservation of the fish species such as P. jullieni and Tor spp., several factors will determine the successful of the egg fertilization. The contributing factors that brought to the success of fish hatching using cryopreserved semen include viability of the post-thaw cryopreserved semen, good quality eggs, handling of the sperm and egg during the fertilization trials and knowledge in culturing the targeted species.

\subsection{Viability of the cryopreserved sperm}

Semen collection for cryopreservation should be done during the peak of spawning seasons of the particular species because the quality and quantity of spermatozoa are the highest at that particular time. The cryopreserved sperm cells tend to deteriorate very quickly and loss their motilily within 10-30 min after thawing procedure. Therefore, in quantification of the quality of the post-thaw sperm, the post-thaw motility shall be evaluated soon after thawing procedure in order to obtain good results. Similarly in the fertilization trials using cryopreserved semen, the mixture of semen to the eggs should be performed as quickly as possible once the frozen semen is thawed. Semen samples from each male broodfish were cryopreserved separately in order to maintain its inherent variability. 
Successful cryopreservation procedures can maintain high quality of cryopreserved semen and this is revealed in high post-thaw sperm motility percentages. Successful cryopreservation procedures balance between the formation of ice crystals within the cells against excessive dehydration, which damages cellular structures (Tiersch, 2000). Each step involved in the cryopreservation procedures that was discussed in section 3 is equally important to produce viable cryopreserved sperm.

\subsection{Good quality eggs}

Good quality egg is also essential for successful fertilization when cryopreserved semen is used to produce offsprings. Same as sperm quality, egg quality is also the best during the peak of spawning seasons of the particular species. Thus fertilization trial is best to perform during spawning seasons of the fish. This is especially true and applicable for the seasonal bred species. In P. jullieni, significant higher fertilization rate (80-95\%) was observed during the peak of the spawning season compared to the initial (50-60\%) and toward the end of breeding season $(30-50 \%)$ of the species. Healthy broodfish produced good quality eggs. Good management practice in broodstocks maintenance and good diet (i.e. high protein diet) are the key factors that produced healthy brood stocks.

\subsection{Handling of sperm and egg during the fertilization trials}

Good control in the timing of egg stripping and thawing of cryopreserved semen is important while using cryopreserved semen to fertilize eggs. Both egg and sperm should be made available at the same time in order to produce high fertilization rates. Spermatozoa of freshwater fishes are usually activated by the hypotonicity of their surrounding media (Morisawa \& Suzuki, 1980; Morisawa et al., 1983a; Morisawa et al., 1983b). Most of the time and in majority species, hatchery water is sufficient as the sperm activation media and used in the sperm-egg mixture during fertilization process with cryopreserved semen. However, the use of suitable medium other than hatchery water for sperm activation is sometimes critical in some species (Lahnsteiner et al., 2003). This is observed in T. tambroides where specially formulated medium produced significant higher fertilization rate compared to the use of hatchery water as the sperm activation medium (Chew et al., 2010b). The effects of several media on egg fertilization ability had also reported by Billard (1983) on rainbow trout. Fertilization technique used in the fertilization trials is also one of the contributing factors to the success. Our studies showed that fertilization and hatching ability were significantly higher by using dry method compared to wet method.

\subsection{Knowledge in culturing of the targeted species}

Knowledge on the reproductive biology, broodstock management and husbandry, larva rearing and nursery of the particular fish species to be studied is a prerequisite for successful fertilization using cryopreserved semen. The age of maturity, breeding season (for seasonal bred species), factors that trigger and promote gonad maturation such as the type of nutrition and water quality where the brood fish is maintained are important factors that guaranteed gonad maturation and good health of the broodfish. Besides, well established artificial spawning method of the targeted species is also essential and such knowledge could later help production of fry using cryopreserved semen. 


\section{Current status of fish sperm cryopreservation in Malaysia -the fish semen cryobank}

The current development of fish sperm cryopreservation in Malaysia is mainly focused on the creation of a fish semen cryobank. Such a cryobank for fish semen plays many important roles, especially for conservation of fish stocks and improve aquaculture. The establishment of a fish semen cryobank requires procurement of equipment and facilities for cryopreservation, skill development of the technical operators, choice of species for semen cryobanking, identification of the source for sample collection, developing of suitable cryopreservation procedure for the targeted species, proper record keeping and also proper maintenance of the semen cryobank.

\subsection{Fish semen cryopresevation for conservation}

Cryopreservation technology provides long term ex situ conservation of indigenous and endangered species (Mongkonpunya et al., 2000; Tiersch et al., 2000). Cryopreserved semen could be stored indefinitely without deterioration provided proper maintenance and handling measures are well taken care of all time (Stoss \& Donaldson, 1983; Armitage, 1987; Suquet et al., 2000). In Malaysia, fish sperm cryopreservation was employed to save the genetics of the endangered and threatened indigenous species such as P. jullieni and Tor spp.. Fish species for gene banking and research are chosen on the basis of their threatened status and potential for aquaculture. Species with vulnerable, critically endangered (CR) and endangered (EN) status are prioritized in a conservation programme (Table 6). Species with protandrous behaviour throughout their life cycle such as the Tenualosa toli (Terubok) is also protected (MACD, 1996; Blaber et al., 2001; Wong, 2001). Other candidates of indigenous fish species which should be prioritized for semen cryopreservation are the Bala Shark (Balantiocheilos melanopterus), the indigenous catfish (Clarias macrocephalus) and several Betta spp. (B. chini, B. hipposideros, B. livida, B. tomi and B. persephone).

Semen samples could be stored for years via cryobanking before being used, and thus cryopreserved sperm banks can serve as insurance policies against unforseen catastrophes. However, very strict standardized protocols should be developed so that results are not biased by experimental and treatment variability but only by the inherent variability of the species. Further, these practices should be complemented with habitat conservation procedures (Bart, 2002). As it takes a long time to restore degraded ecosystems, the preserved semen is stored while upgrading of the ecosystems is going on. Both in situ and ex situ conservation should be applied complimentarily for sustainable management of the indigenous fisheries resources (Harvey, 1998). For an instance in the conservation programme of $P$. jullieni, introduction of closing season (from February to April each year) and conservation zones $(12.4 \mathrm{~km})$ at the identified spawning ground of $P$. jullieni at Pahang River have been implemented as the in situ conservation approach for the species (Zulkafli et al., 2010).

Conservation of indigenous freshwater fishes is a priority of the Department of Fisheries, Malaysia. Resulting from the success in breeding both $P$. jullieni and Tor spp. using cryopreserved semen, cryobanking of the semen of these species was initiated in 2008. However, those samples were collected from the cultured stock. Therefore, effort to further enrich the sperm cryobank through collection from wild stocks for different varieties and 
populations in the country is the ultimate aim of the Department of Fisheries, Malaysia. At present, semen samples from 88 Tor spp., 43 P. jullieni, 8 P. nasutus and $14 \mathrm{H}$. wetmorei have been collected and cryopreserved in the sperm cryobank of FRI Glami Lemi (Table 7).

The use of cryopreserved semen could support conservation efforts through stock enhancement and repopulation in areas where the species have declined or disappeared. In the breeding and restocking programmes, attempts to save the wild populations have so far largely focused on captive breeding or spawning of wild broodstock and subsequent release of hatchery-reared offsprings into the wild. Hatchery production of fry will support stock enhancement. Consequently, this will hopefully eliminate the need to harvest seed stock from the wild and the translocation of non-indigenous species for such programme.

\begin{tabular}{ll}
\hline \multicolumn{1}{c}{ Species } & Status \\
\hline Balantiocheilos melanopterus (Bala shark) & EN \\
Betta chini (Chini mouthbrooder) & VU \\
Betta hipposideros & VU \\
Betta livida (Emerald-sport fighting fish) & EN \\
Betta persephone (Black fighting fish) & CR \\
Betta tomi (Pikehead) & VU \\
Discherodontus halei (Spot-fin barb) & CR \\
Eleotris melanosoma & CR \\
Encheloclarias curtisoma (Soft fin walking catfish) & CR \\
Encheloclarias kelioides (Soft fin walking catfish) & CR \\
Encheloclarias prolatus (Catfish) & VU \\
Parasphromerus harveyi (Harvey's licorice gouramy) & EN \\
Probarbus jullieni (Isok barb) & EN \\
Scleropages formosus (Asian Arowana) & EN \\
Silurus furness & DD \\
Redigobius bikalanus & CR \\
Phallostethus dunckeri & VU \\
Sundoreonectes tiomanensis (Tioman cave loach) & VU \\
Helicophagus waandersii & EN \\
Cyclocheilichthys enoplus & EN \\
Leptobarbus hoeveni (Mad barb) & EN \\
\hline
\end{tabular}

(Source: DOF, Malaysia; Chong et al., 2010)

Table 6. List of indigenous freshwater fish species in Malaysia with critically endangered $(\mathrm{CR})$, endangered $(\mathrm{EN})$, vulnerable (VU) or data deficient (DD) status.

\begin{tabular}{ccc}
\hline Species & Number of fish & Volume \\
\hline Tor spp. & 88 & $150 \mathrm{~mL}$ \\
P.jullieni & 43 & $350 \mathrm{~mL}$ \\
P. nasutus & 8 & $18 \mathrm{~mL}$ \\
H. wetmorei & 14 & $30 \mathrm{~mL}$ \\
\hline
\end{tabular}

Table 7. Current status of cryogenic fish sperm bank of FRI Glami Lemi, Malaysia (since 2008) 


\subsection{Fish semen cryopreservation for aquaculture}

Fish gene banks offer vast potential benefits to hatcheries (Munkittrick \& Moccia, 1984; Chao \& Liao, 2001). It offers genetic variability to fish hatcheries around the world. The use of frozen semen in breeding programmes offers a means to further broaden the genetic base of the targeted species. Genetic improvement of broodstock or hatchery species for traits such as disease resistant, fast growth rate, salinity tolerance etc. could also make feasible with the establishment of the cryogenic sperm bank. The applications of sperm cryopreservation in aquaculture were also highlighted by Mongkonpunya et al. (2000). In the case of some species, males and females reach maturity over different periods of time, the cryopreserved semen could facilitate artificial fertilization and seed production (Tiersch, 2000). Besides, cryopreserved semen is easier to transport than live fish for culturing. This eliminates the stress to fish. The risk of transmitting diseases is also reduced by using cryopreserved semen.

On the other hand, the use of cryopreserved sperm also provides flexibility in breeding programmes, especially in producing hybrids with favourable characteristics for culturing such as higher viability, intensive growth rate, adaptive flexibility, early sexual maturation etc. (FAO, 1971). Hybridization in fish culture becomes feasible and more manageable with the utilization of cryopreserved semen. For example, in a breeding programme of $H$. wetmorei carried out in our laboratory, $H$. wetmorei was cross-bred with the Javanese barb, B. gonionotus successfully via the use of cryopreserved sperm and surrogate egg from B. gonionotus. Such breeding procedure was needed because mature female of $H$. wetmorei was not available during the induced breeding programme of the species. Therefore, it is no doubt that the use of cryopreserved sperm provides greater control in breeding programmes.

\section{Challenges to the gene banking of fish gamete via cryopreservation}

\subsection{Procedure optimization}

The principle and process behind semen cryopreservation sound rather simple, i.e. the storage of semen samples in ultra-low temperatures and liquid nitrogen $\left(-196^{\circ} \mathrm{C}\right)$ is normally used. In avian species (such as chicken, fowl, turkey, goose and duck) and mammal livestock species (such as cattle, horse, boar, sheep and goat), protocols for their semen cryopreservation are well developed and established (Hammerstedt \& Graham, 1992; Curry, 2000; Donoghue \& Wishart, 2000; Woelders et al., 2003). In fish however, there are no standard protocols that are applicable to all species. Unlike terrestrial animals, it is more difficult to standardize the semen cryopreservation protocols in fish (Tiersch, 2000). This is because different fish species exhibited different responses to the same extenders and cryoprotectants. For an example, the protocol or diluents formulation which served optimal to $P$. jullieni may not be necessarily suitable and served optimum in other species. As such, developing the species-specific and reproducible sperm cryopreservation procedure is thus required for this purpose. These include the choice of the type of extender solution and cryoprotectant, the rates of freezing and thawing etc. In general, the optimization of cryopreservation protocol for a species involved a series of complex interactions among various factors in each step.

\subsection{Maintenance and proper recording}

It is less costly to maintain a semen cryobank in a long run compared to in situ conservation approach such as live genebank. However, some costs need to be allocated for replenishing 
and topping up of liquid nitrogen in the storage dewars on periodically basis. Obtaining adequate funding and financial support to maintain the semen cryobank is part of the challenges to the institutions owned a semen cryobank. The monitoring of the viability of cryopreserved semen samples is also required from time to time to ensure the viability of stored samples is maintained. Post-thaw sperm motility was assessed for each batch of semen samples a week after cryo-storage and prior to be used for egg fertilization. The viability of the cryopreserved sperm was also evaluated from time to time through egg fertilization tests. A database that is able to provide good records of storage and withdrawals of samples from the semen cryobank is also a long term challenge in genebanking via cryopreservation (Kincaid, 2000). Proper record is essential for ease of samples retrieval in future.

\subsection{Technical limitations}

There are technical limitations to use cryopreserved semen in fish breeding as it requires involvement of skilled personnels. Therefore, training of operators or technicians in the related discipline is seen required in the technology extension programme. The small volume sample in straws $(0.25 \mathrm{~mL}$ and $0.5 \mathrm{~mL})$ is sufficient to be used in egg fertilization in laboratory based experiments and in genetic improvement programme of the targeted species. However, it is less practical to use cryopreserved semen for mass production of fry in aquaculture. Adaptation of the current developed protocols for practical application is thus important. The use of bigger straws volume or cryovials $(5 \mathrm{~mL}$ or $10 \mathrm{~mL})$ should be considered instead.

\subsection{Difficulties in obtaining semen samples from wild populations}

Difficulties in getting wild stocks are the main constraints in fish semen cryobanking of the indigenous species with threatened or endangered status and those species with high market demand. These limitations have caused difficulties in obtaining the effective population size $\left(\mathrm{N}_{\mathrm{e}}\right)$, which is very crucial in future restoration efforts for the species. High quality seed is essential to support aquaculture. For many species especially of those riverine species, which their induced breeding method is still not established, their source of seed supply is still depend on the wild caught stocks. In Malaysia, it is also difficult to obtain fry and broodstock from hatchery because the lack of well organised hatchery operation. Each hatchery tends to maintain their own breeders, which is always limited in numbers. As the consequences, this resulted in high inbreeding rates among the hatchery stocks.

In Malaysia, it is now increasingly difficult for fish breeders to locate and collect genetic materials from healthy or relatively undisturbed populations in the wild. The loss of genetic material in fish species can hinder the development of the aquaculture industries, especially fish farms and hatcheries. Many hatcheries often rely on too few breeders to reproduce, resulting in lower production, susceptibility to diseases and poor survival rates in the wild. As wild fish stocks disappear, it becomes even more difficult for hatcheries to find new breeders. At the same time breeding within small populations with limited genetic diversity results in inbreeding depression, i.e. genetic drift, producing small or stunted fish stocks. Therefore, fish genetic resources must be conserved and utilized sustainably because they are the key to maintaining the viability of cultured and natural fish populations. They 
enable species to adapt to environmental change and also provide the opportunity for genetic improvement programme in aquaculture.

It is observed that large species that breed later in life are more vulnerable to fishing and changes in the environment, particularly in terms of fragmentation of their normal habitats. Indeed, most of the world's largest freshwater fish are at risk according to the IUCN Red List, and over exploitation contributes in a number of these cases. The dragon fish, Scleropages formosus is a well known case of over-exploitation. Therefore, giant indigenous species such as freshwater siluroids (Wallago leeri,), cyprinids (Tor spp., Probarbus jullieni), pangasiids (Helicophagus waandersii) etc. can be promoted as 'flagship species' or ecosystem ambassadors. At the same time, in terms of preserving biodiversity, by reducing the negative impacts of the continued spread of exotic fish species in the aquatic environment, efforts need to develop indigenous species for use in aquaculture. Those indigenous species that showed good adaptation to pond environment, resistance to handling, possess high growth rate and ability to reach sexually maturity in captivity are worth to be considered and developed as aquaculture species. To achieve the goal, we must safeguard indigenous fish resources both quantitatively and qualitatively from now before it is too late.

\section{Conclusion}

An overview of the current status of semen cryopreservation of Malaysian freshwater fishes is presented in this chapter. The role of semen cryobank is also discussed. Obviously, semen cryopreservation offers potential applications in ex situ conservation and sustainable management of the fisheries genetic resources in Malaysia, especially for those species with rare, vulnerable, threatened or endangered status, those protandry species with sexchanging characteristic over their life time, and also the potential candidates and genetic improved strains for aquaculture development. The successes in semen cryopreservation are very much relied on factors such as having ample knowledge on the biology and reproductive biology of the particular species of interest, trained personnels in various aspects such as gamete cryopreservation, breeding methods, broodstock management and husbandry and larva rearing and nursing of the targeted species.

\section{Acknowledgement}

We would like to thank the Department of Fisheries Malaysia for supporting this research through a development grant and also thanks to all research staffs of Freshwater Fisheries Research Division, FRI Glami Lemi and the Aquaculture Extension Centre, Perlok who have kindly provided assistance during the project.

\section{References}

Aas, G.H.; Refstie, T. \& Gjerde, B. (1991). Evaluation of milt quality of Atlantic salmon. Aquaculture, 95: 125-132.

Ahmad-Ashhar, O. (1992). Induced spawning of Ikan Temoleh Probarbus jullieni Sauvage using human chrionic gonadotropin and heteroplastic crude piscine extract. In: Proceedings of the National IRPA Seminar, Kuala Lumpur, 9-11 January 1992. pp. 243-244. 
Ahmad-Ashhar, O. (1996). Breeding and seed production technology of the Jelawat (Leptobarbus hoevenii).

Ahmad-Ashhar, O. (1998). Pembiakan Dan Pengeluaran Benih Ikan Jelawat (Leptobarbus hoevenii) Bleeker. Buku Panduan Bil 2/98. 21pp.

Ahmad-Ashhar, O. \& Haron, A. (1994). Pembiakan aruhan Ikan Temoleh Probarbus jullieni Sauvage menggunakan ekstrak pituitari dan hormon human chorionic gonadotrophin (H.C.G.). Proc. Fish. Res. Conf., DOF, Mal. IV: 253-256.

Allan, J.D., Abell, R., Hogan, Z., Revenga, C., Taylor, B.W., Welcomme, R.L. \& Winemiller, K. (2005). Overfishing of Inland Waters. BioScience 55(12): 1041-1051.

Ambak, M.A., Ashraf, A.H. \& Budin, S. (2007). Conservation of the Malaysian Mahseer in Nenggiri basin through community action.

Babiak, I., Glogowski, J., Goryczko, K., Dobosz, S., Kuzminski, H., Strzezek, J. \& Demianowicz, W. (2001). Effect of extender composition and equilibration time on fertilization ability and enzymatic activity of rainbow trout cryopreserved spermatozoa. Theriogenology 56: 177-192.

Baird, I. G. (2006). Probarbus jullieni and Probarbus labeamajor: the management and conservation of two of the largest fish species in the Mekong River in southern Laos. Aquatic Conservation: Marine and Freshwater Ecosystems 16(5): 517-532.

Baluyut, E. (1983). Stocking and introduction of fish in lakes and reservoirs in the ASEAN region. FAO Tech. Pap. 236. 82 pp.

Bart, A. (2002). Conservation of fish genetic diversity: need for development of a cryogenic genebank in Bangladesh. In: Penman, D.J., Hussain, M.G., McAndrew, B.J. and Mazid, M.A. (eds.) Proceedings of a workshop on Genetic Management and Improvement Strateges for Exotic Carps in Asia, 12-14 February 2002. Dhaka, Bangladesh. Pp 107-110.

Billard, R. (1983). Effects of cleolomic and seminal fluids and various saline diluents on the fertilizing ability of spermatozoa in the Rainbow trout, Salmo gairdneri. J. Reprod. Ferti., 68: 77-84.

Billard, R. (1986). Spermatogenesis and spermatology of some teleost fish species. Reprod. Nutr. Dev., 2: 877-920.

Billard, R. \& Cosson, M.P. (1992). Some problems related to the assessment of sperm motility in freshwater fish. J. Exp. Zool., 261: 122-131.

Billard, R., Cosson, J., Crim, L.W. \& Suquet, M. (1995). Sperm physiology and quality. In: Brood stock management and egg and larval quality. (Eds) Bromage, N. R. and Roberts, R.J. Blackwell Science, Oxford. pp. 25-52.

Blaber, S.J.M., Milton, D.A., Brewer, D.T. \& Salini, J.P. (2001). The shads (genus Tenualosa)of tropical Asia: An overview of their biology, status and fisheries. In: Proceedings of the International Terubok Conference Sarawak, Malaysia, 11 -12 September 2001, Sarawak. pp. 9-17.

Butts, I.A.E., Trippel, E.A. \& Litvak, M.K. (2009). The effect of sperm to egg ratio and gamete contact time on fertilization success in Atlantic cod Gadus morhua L. Aquaculture 286 $(1-2): 89-94$.

Chao, N.H. \& Liao, I.C. (2001). Cryopreservation of finfish and shellfish gametes and embryos. Aquaculture 197: 161-189.

Chew, P.C., Hassan, R., Rashid, Z. A. \& Chuah, H.P. (2010a). The endangered Probarbus jullieni (Sauvage) - Current status on its sperm cryopreservation in Malaysia. Journal of Applied Ichthyology 26: 797-805.

Chew, P.C., Rashid, Z. A., Hassan, R., Asmuni, M. \& Chuah, H.P. (2010b). Semen cryo-bank of the Malaysian Mahseer (Tor spp.) Journal of Applied Ichthyology 26: 726-731. 
Chong, V.C., Lee, P.K.Y. \& Lau, C.M. (2010). Diversity, extinction risk and conservation of Malaysian fishes. Journal of Fish Biology 76: 2009-2066.

Curry, M.R. (2000). Cyopreservation of semen from domestic livestock. Reviews of Reproduction 5: 46-52.

Dobriyal, A.K., Kumar, N., Bahuguna, A.K. \& Singh, H.R. (2000). Breeding ecology of some cold water minor carps from Garhwal Himalayas. Coldwater Fish and Fisheries: 177-186. (Eds) Singh, H.R. and Lakra, W.S. Narenda Publishing House, New Delhi. 337p.

DOF. (n.d.). Endangered freshwater fish species in Malaysia under the IUCN Red List. In: $3^{\text {rd }}$ January 2011. Available from: <http://www.dof.gov.my/c/document_library/get_file?uuid=d8ebcbc5-4d4a-4125-8290$5 d 5 b d 78 b 1 a 5$ cEgroupId $=172176>$.

Donoghue, A.M. \& Wishart, G.J. (2000). Storage of poultry semen. Animal Reproduction Science 62: 213-232.

Dreanno, C., Suquet, M., Quemener, L., Cosson, J., Fierville, F., Normant, Y. \& Billard, R. (1997). Cryopreservation of turbot (Scophthalmus maximus) spermatozoa. Theriogenology 48: 589-603.

Dudgeon, D. (2002). Fisheries : pollution and habitat degradation in tropical Asian rivers. Encyclopaedia of Global Environmental Change, Vol. III (ed. I. Douglas), pp. 316-323. John Wiley \& Sons, Chichester, U.K.

FAO. (1971). Seminar/Study Tour in the U.S.S.R. on Genetic Selection and Hybridization of Cultivated Fishes. 19 April - 29 May 1968. Lectures. Rep.FAO/UNDP(TA), (2926): $360 \mathrm{p}$.

Froese, R., \& Pauly, D. (2003). (Eds.). Fishbase. In: World Wide Web electronic publication, 3rd January 2011. Available from: <http://www.fishbase.org $>$.

Gwo, J.C. (2000). Cryopreservation of sperm of some marine fishes. In Tiersch, T.R. and Mazik, P.M. (Eds.), Cryopreservation in Aquatic Species. World Aquaculture Society, Baton Rouge, L.A. pp. 138-160.

Gwo, J.C., Strawn, K., Longnecker, M.T. \& Arnold, C.R. (1991). Cryopreservation of Atlantic croakker spermatozoa. Aquaculture 94: 355-375.

Hammerstedt, R.H. \& Graham, J.K. (1992). Cryopreservation of poultry sperm: the enigma of glycerol. Cryobiology 29: 26-38.

Harvey, B. (1998). An overview of action before extinction. In: Harvey B, Ross C, Greer D, Carolsfeld J (eds) Action before extinction: an international conference on conservation of fish genetic diversity. World Fisheries Trust, Victoria Inger, F.R. and Chin, P.K. 1962. The Freshwater Fishes of North Borneo. Chicago Natural History Muzeum, Chicago.

Ho, S.C. (1995). Status of Limnological Research and Training in Malaysia. In: Limnology in Developing Countries (eds B. Gopal and R.G. Wetzel). International Association for Limnology. International Scientific Publications, 50-B., Pocket C., Sidhartha Extension, New Delhi. Pp 163-189.

Hogan, Z., Baird, I.G. \& Phanara, T. (2009). Threatened fishes of the world: Probarbus jullieni Sauvage, 1880 (Cypriniformes: Cyprinidae). Environ. Biol. Fish 84: 291-292.

Honeyfield, D.C. \& Krise, W.F. (2000). Measuament of milt quality and factors affecting viability of fish spermatozoa. In: Tiersch, T.R. and Mazik, P.M. (Eds.), Cryopreservation in Aquatic Species. World Aquaculture Society, Baton Rouge, L.A. pp. 49-58.

Horvath, A., Miskolczi, E. \& Urbányi, B. (2003). Cryopreservation of common carp sperm. Aquat. Living Resour. 16: 457-460. 
Hung, L. T., Suhenda, N., Slembrouck, J., Lazard, J. \& Moreau, Y. (2004). Comparison of dietary protein and energy utilization in three Asian catfishes (Pangasius bocourti, $P$. hypophthalmus and P. djambal). Aquaculture Nutrition 10: 317-326.

Inger, R.F. (1955). Ecological notes on the fish fauna of a coastal drainage of north Borneo. Fieldiana Zool. 37: 47 -90.

Inger, R.F. \& Chin, P.K. (1962). The Freshwater Fishes of North Borneo. Fieldiana Zool. 45: 1268.

Inger, R.F. \& Chin, P.K. (2002). The Freshwater Fishes of North Borneo with a supplementary chapter by Chin Phui Kong. Natural History Publications (Borneo), Kota Kinabalu. 268 pp. + S-78.

Ingram, B., Sungan, S., Gooley, G., Sim, S.Y., Tinggi D. \& de Silva S.S. (2005). Induced spawning, larval development and rearing of two indigenous Malaysian Mahseer, Tor tambroides and T. duoronensis. Aquacult. Res. 36(10): 1001-1014.

IUCN (2009). IUCN Red List of Threatened Species. Version 2009.1. <www.iucnredlist.org>. Downloaded on 25 August 2009.

Jackson, D.C. \& Marmulla, G. (2001). The influence of dams on river fisheries. In Dams, fish and fisheries: Opportunities, challenges and conflict resolution (ed. Marmulla, G.). FAO Fisheries Technical Paper 419: 1-45.

Jantrarotai, P., Sutthiwises, S., Kamonrat, V., Peyachoknagul, S. \& Vidthayanon, C. (2007). Species identification of 3 Hypsibarbus spp. (Pisces: Cyprinidae) using PCR-RFLP of cytochrome b gene. Kasetsart J. (nat. Sci.) 4: 660 - 666.

Khan, M.S. (1987). Some aspects of the biology of ikan baung, Mystus nemurus C. \& V. with reference to Chenderoh Reservoir. Thesis of MSc. Universiti Pertanian Malaysia, Serdang.

Khan, M.S., Ambak, M.A., Ang, K.J. \& Mohsin, A.K.M. (1995). Reproductive biology of a tropical catfish, Mystus nemurus Cuvier and Valenciennes, in Chenderoh Reservoir Malaysia. Aquaculture and Fisheries Management 21: 173-179.

Khoo, K.H., Leong, T.S., Soon, F.L., Tan, S.P. \& Wong, S.Y. (1987). Riverine fisheries in Malaysia. Archiv. feur Hydrobiologie Beiheft. 28: 261 - 268.

Kincaid, H.L. (2000). Development of Databases for Germplasm Repositories. In: Tiersch, T.R. and Mazik, P.M. (eds) Cryopreservation in Aquatic Species. World Aquaculture Society, Baton Rouge.Pp 323-331.

Kopeika, E., Kopeika, J. \& Zhang, T. (2007). Cryopreservation of fish sperm. In: Day, J.G. and Stacey, G.N. (Eds) Methods Mol. Biol. Vol. 368: Cryopreservation and Freeze-Drying Protocols, $2^{\text {nd }}$ edition. Humana Press Inc., Totowa, NJ. pp. 203 -217.

Kottelat, M., Whitten, A.J., Kartokasari, S.N. \& Wirjoratmodjo, S. (1993). Freshwater Fishes of Western Indonesia and Sulawesi. Singapore: Berkeley Book Pte Ltd.

Kurokura, H., Hirano, R., Tomita, M. \& Iwahashi, M. (1984). Cryopreservation of carp sperm. Aquaculture 37: 267-273.

Lahnsteiner, F. \& Patzner, R.A. (2008). Sperm morphology and ultrastructure in fish. In: Alavi, S.M.H., Cosson, J.J., Coward, K. and Rafiee, G. (Eds) Fish Spermatology. Alpha Science International Ltd., Oxford, UK. pp. 1-61.

Lahnsteiner, F., Patzner, R.A. \& Weismann, T. (1996). Semen cryopreservation of salmonid fishes: influence of handling parameters on the post thaw fertilization rate, Aquacult. Res. 27(9): 659-671.

Lahnsteiner, F., Weismann, T. \& Patzner, A.R. (1997). Methanol as cryoprotectant and the suitability of $1.2 \mathrm{ml}$ and $5 \mathrm{ml}$ straws for cryopreservation of semen from salmonid fishes. Aquaculture Research 28: 471-479. 
Lahnsteiner, F., Berger, B. \& Weismann, T. (2003). Effects of media, fertilization technique, extender, straw volume, and sperm to egg ratio on hatchability of cyprinid embryos, using cryopreserved semen. Theriogenology 60: 829-841.

Leung, L.K.P. \& Jamieson, B.G.M. (1991).Live preservation of fish gametes. In: Jamieson, B.G.M. (Ed.), Fish Evolution and Systematics: Evidence from Spermatozoa. Cambridge Univ. Press, Cambridge, pp. 245-269.

Maack, G.G. \& George, M.R. (1999). Contributions to the reproductive biology of Encrasicholina punctifer Fowler, 1938 (engraulidae) from West Sumatra, Indonesia. Fisheries Research 44: 113 - 120.

MACD (1996). Life Cyle of Terubok (Tenalosa toli) With Recommendations for the Conservation, Management and Culture of The Species. Phase 3 Final Report. A collaborative project of CSIRO Division of Fisheries, Marine Laboratories, Cleveland Queensland, Australia and Inland Fisheries Branch, Ministry of Agriculture \& Community Development (MACD), Kuching. Pp.64.

Mohamad-Zaini S. (1992). Pembiakan Aruhan Dan Pengeluaran Benih Ikan Sebarau Hampala macrolepidota. Buletin Perikanan $82.13 \mathrm{pp}$.

Mohd-Zafri, H. (2006). Morphology and general reproductive stages of Pangasius nasutus from Sg. Pahang in Maran District, Pahang, Malaysia. Thesis Msc, UPM.

Mohsin, A.K.M. \& Ambak, M.A. (1991). Freshwater Fishes of Peninsular Malaysia. Penerbit Universiti Pertanian Malaysia, Serdang, Selangor.

Mongkonpunya, K., Pupipat, T. \& Tiersch, T.R. (2000). Cryopreservation of sperm of Asian Catfishes including the endangered Mekong Giant Catfish. In: Tiersch, T.R. and Mazik, P.M. (Eds.), Cryopreservation in Aquatic Species. World Aquaculture Society, Baton Rouge, L.A. pp. 108-116.

Morisawa, M. \& Suzuki, K. (1980). Osmolality and potassium ion: Their roles in initiation of sperm motility in eleosts. Science 210: 1145 - 1147.

Morisawa, M., Suzuki, K. \& Morisawa, S. (1983a). Effects of potassium and osmolality on spermatozoan motility of Salmonid fishes. Journal of Experimental Biology 107: 105 113.

Morisawa, M., Suzuki, K., Shimizu, H., Morisawa, S. \& Yasuda, K. (1983b). Effects of potassium and osmolality on motility of spermatozoa from freshwater cyprinid fishes. Journal of Experimental Biology 107: 95 - 103.

Muchlisin, Z.A., Hashim, R. \& Chong, A.S.C. (2004). Preliminary study on the cryopreservation of tropical bagrid catfish (Mystus nemurus) spermatozoa: the effect of extender and cryoprotectant on the motility after short-term storage. Theriogenology 62: 25-34.

Munkittrick, K.R. \& Moccia, R.D. (1984). Advances in the cryopreservation of salmonid semen and suitability for a production-scale artificial fertilization program. Theriogenology 21: 645-59.

$\mathrm{Ng}$, C.K. (2004). Kings of the Rivers - Mahseer in Malaysia and the region. Inter Sea Fishery (M) Sdn. Bhd. Selangor.

Nguyen, T.T.T. (2008). Population structure in the highly fragmented range of Tor douronensis (Cyprinidae) in Sarawak, Malaysia revealed by microsatellite DNA markers. Freshwater Biology 53: 924-934.

Nguyen, T.T.T., Baranski, M., Rourke, M. \& McPartlan, H. (2006). Characterisation of microsatellite DNA markers for the mahseer species, Tor tambroides and crossamplification in other four congeners (T. douronensis, T. khudree, T. putitora, and T. tor). Molecular Ecology Notes 7: 109-112. 
Nguyen, T.T.T., Ingram, B., Sungan, S., Gooley, G., Sim, S.Y., Tinggi, D. \& De Silva, S.S. (2006). Mitochondrial diversity of broodstock of two indigenous mahseer species, Tor tambroides and T. douronensis (Cyprinidae) cultured in Sarawak, Malaysia. Aquaculture 253: 259-269.

Nguyen, T.T.T., Ingram, B., Sungan, S., Tinggi, D., Sim, S.Y., Gooley, G. \& De Silva, S. S. (2007). Guidelines for genetic management and conservation of two mahseer species in Sarawak, Malaysia. (Downloaded on 20 October 2009)

Nguyen, T.T.T., Sukmanomon, S., Na-Nakorn, U. \& Ziming, C. (2008). Molecular phylogeny and phylogeography of mahseer species (Cyprinidae: Cypriniformes) as inferred from sequences of two mitochondrial gene regions. Molecular Phylogenetics and Evolution (in press) (doi:10.1016/j.ympev.2008.01.006).

Pathmasothy, S. (1985). The Effect of Three Diets with Variable Protein Level on Ovary Development and Fecundity in Leptobarbus hoevenii. In: Cho, C.Y., D.S. Cowey and W. Watanabe, Finfish Nutrition in Asia; Methodological Approach to Research and Development. Proceedings of the Asian Finfish Nutrition Workshop Held in Singapore 23-2 August, 1983. Ottawa: IDRC., pp.107-112.

Pathmasothy, S., \& R. Omar. (1982). The Effect of Four Different Diets on the Growth of Leptobarbus hoevenii. MARDI Research Bulletin 10(1): 100-113.

Rainboth, W.J. (1996). Fishes of the Cambodian Mekong. FAO Species Identification Field Guide for Fishery Purposes. Food and Agriculture Organization (FAO) Publication, Rome.

Rideout, R.M., Litvak, M.K. \& Trippel, E.A. (2003). The development of a sperm cryopreservation protocol for winter flounder, Pseudopie-uronectes americanus (Walbaum): evaluation of cryoprotectants and diluents. Aquaculture Research 34: 653-659.

Roberts, T.R. (1989). The Freshwater Fishes of Western Borneo (Kalimantan Barat, Indonesia).California Academy of Sciences, California.

Roberts, T.R. (1992). Revision of the Southeast Asian cyprinid fish genus Probarbus, with two new species threatened by the proposed construction of dams on the Mekong River. Ichthyl. Expl. Freshw. 3: 37-48.

Roberts, T.R. \& Vidthayanon, C. (1991). Systematic revision of the Asian catfish family Pangasiidae, with biological observations and description of three new species. Proceedings of the Academy of NaturalSciences of Philadelphia 143: 97-144.

Saidin, T. (1986). Induced spawning of Clarias macrocephalus (Gunther). In: Maclean, J.L., Dizon, L.B. \& Hosillos, L.V. (eds.) The First Asian Fisheries Forum. Asian Fisheries Society, Manila, Philipines. P. $683-686$.

Scott, A.P. \& Baynes, S.M. (1980). A review of the biology, handling and storage of salmonid spermatozoa, J. Fish Biol. 17: 707-739.

Stoss, J \& Donaldson, E.M. (1983). Studies on cryopreservation of eggs from rainbow trout (Salmo gairdneri) and coho salmon (Oncorhynchus kisutch). Aquaculture 31: 51 - 65.

Suhairi, A. (1996). Preliminary observations on the culture of the Temoleh (Probarbus jullieni) in ponds. Paper presented in Fisheries Semeniar July 1996, IPP Batu Maung, Pulau Pinang, Malaysia.

Suhairi, A., Misri, S., Abdul Ghani, H. \& Ahmad Ashhar, O. (1996). Kajian awal ternakan ikan temoleh (Probarbus jullieni) dalam kolam. Proc. Fish. Res. Conf., DOF, Mal., 1996: 278-283.

Suquet, M., Omnes, M.H., Normant, Y. \& Fauvel, C. (1992). Assessment of sperm concentration and motility in turbot Scophthalmus maximus. Aquaculture 101: 177185. 
Suquet, M., Dreanno, C., Fauvel, C., Cosson, J. \& Billard, R. (2000). Cryopreservation of sperm in marine fish. Aquaculture Research 31: 231-243.

Thalathiah, S., Abas Fauzi, O. \& Ibrahim, T. (1988). First successful attempt to induce breed Mystus nemurus (C \& V) at Batu Berendam, Melaka. Proc. 11 th Ann. Conf. MSAP: 53 $-55$.

Thalathiah, S., Ibrahim, T. \& Mansor, A. (1992). Induced spawning of Mystus nemurus (C \& V) using heteroplastic pituitary extract, HCG and an analog of LHRH. In: Proceedings of Fisheries Research Seminar, Malacca, 27 - 29 June 1989. Pp. 185 - 188.

Tiersch, T.R. (2000). Introduction. In: Tiersch, T.R. and Mazik, P.M. (Eds.), Cryopreservation in Aquatic Species. World Aquaculture Society, Baton Rouge, L.A. pp. 19-26.

Tiersch, T.R. (2006). Fish sperm cryopreservation for genetic improvement and conservation in Southeast Asia. Fish For The People 4(2): 21-33.

Tiersch, T.R., Goudie, C.A. \& Carmichael, G.J. (1994). Cryopreservation of channel catfish sperm: storage in cryoprotectants, fertilization trials, and growth of channel catfish produced with cryopreserved sperm. Transactions of the American Fisheries Society 123: 580-586.

Tiersch, T.R., Figiel, C.R., Wayman, Jr., W.R., Williamson, J.H., Carmichael, G.J. \& Gorman, O.T. (2000). Cryopreservation of sperm of the endangered razorback sucker. In: Tiersch, T.R. and Mazik, P.M. (Eds.), Cryopreservation in Aquatic Species. World Aquaculture Society, Baton Rouge, L.A. pp. 117-122.

Tsigenopoulos, C.S. \& Berrebi, P. (2000). Molecular phylogeny of North Mediterranean freshwater barbs (Genus Barbus: Cyprinidae) inferred from cytochrome b sequences: biogeographic and systematic implications. Molecular Phylogenetics and Evolution 14: 165-179.

Wamecke, D. \& Pluta, H.J. (2003). Motility and fertilizing capacity of frozen/thawed common carp (Cyprinus carpio L.) sperm using dimethyl-acetamide as the main cryoprotectant. Aquaculture 215: 167-185.

Woelders, H. Zuidberg, C.A. \& Hiemstra, S.J. (2003). Applications, limitations, possible improvements and future of cryopreservation for livestock species. In: Proceedings of the Workshop on Cryopreservation of Animal Genetic Resources in Europe. Paris, 23 ${ }^{\text {rd }}$ February 2003. pp 67-76.

Wolf, K. (1963). Physiological salines for freshwater teleosts. The Progressive. Fish Culturist. 25: $135-140$.

Wong, P. P. H. (2001). The status of the Terubok (Tenualosa toli) fishery in Sarawak, Malaysia. In: Proceedings of the International Terubok Conference Sarawak, Malaysia, 11 -12 September 2001, Sarawak. pp. 91-99.

Zhang, Y.Z., Zhang, S.C., Liu, X.Z., Xu, Y.Y., Wang, C.L., Sawant, M.S., Li, J. \& Chen, S.L. (2003). Cryopreservation of flounder (Paralichthys olivaceus) sperm with a practical methodology. Theriogenology 60: 989-996.

Zhou, W. \& Chu, G.H. (1996). A review of Tor species from the Lancangjiang River (Upper Mekong River), China (Teleostei: Cyprinidae). Ichthyological Exploration of Freshwater 7: 131-142.

Zulkafli A.R., Chew, P.C. \& Johari, I. (2010). Conservation of Freshwater Fishes and Enhancement Programmes in Peninsular Malaysia. 2nd National Conference on Agrobiodiversity Conservation and Sustainable Utilization (NAC2)-Agrobiodiversity for sustainable economic development, 11-13 May 2010, Tawau, Sabah. Pp 48-50. 


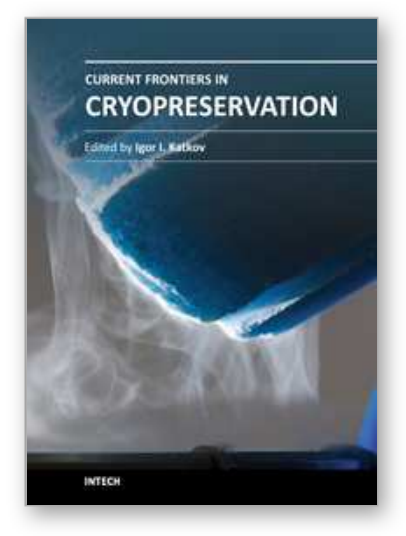

\author{
Current Frontiers in Cryopreservation \\ Edited by Prof. Igor Katkov
}

ISBN 978-953-51-0302-8

Hard cover, 462 pages

Publisher InTech

Published online 14, March, 2012

Published in print edition March, 2012

Almost a decade has passed since the last textbook on the science of cryobiology, Life in the Frozen State, was published. Recently, there have been some serious tectonic shifts in cryobiology which were perhaps not seen on the surface but will have a profound effect on both the future of cryobiology and the development of new cryopreservation methods. We feel that it is time to revise the previous paradigms and dogmas, discuss the conceptually new cryobiological ideas, and introduce the recently emerged practical protocols for cryopreservation. The present books, "Current Frontiers in Cryobiology" and "Current Frontiers in Cryopreservation" will serve the purpose. This is a global effort by scientists from 27 countries from all continents and we hope it will be interesting to a wide audience.

\title{
How to reference
}

In order to correctly reference this scholarly work, feel free to copy and paste the following:

Poh Chiang Chew and Abd. Rashid Zulkafli (2012). Sperm Cryopreservation of Some Freshwater Fish Species in Malaysia, Current Frontiers in Cryopreservation, Prof. Igor Katkov (Ed.), ISBN: 978-953-51-0302-8, InTech, Available from: http://www.intechopen.com/books/current-frontiers-in-cryopreservation/spermcryopreservation-of-some-freshwater-fish-species-in-malaysia

\section{INTECH}

open science | open minds

\section{InTech Europe}

University Campus STeP Ri

Slavka Krautzeka 83/A

51000 Rijeka, Croatia

Phone: +385 (51) 770447

Fax: +385 (51) 686166

www.intechopen.com

\section{InTech China}

Unit 405, Office Block, Hotel Equatorial Shanghai

No.65, Yan An Road (West), Shanghai, 200040, China

中国上海市延安西路65号上海国际贵都大饭店办公楼 405 单元

Phone: +86-21-62489820

Fax: $+86-21-62489821$ 
(C) 2012 The Author(s). Licensee IntechOpen. This is an open access article distributed under the terms of the Creative Commons Attribution 3.0 License, which permits unrestricted use, distribution, and reproduction in any medium, provided the original work is properly cited. 